\title{
Application of the Humic Substances and Ammonia in Order to Minimize Losses on Nitrogen Fertilization
}

\author{
Luciana Teresa Dias Cappelini*, Lia Gracy Rocha Diniz, Ana Luiza Fornazari, \\ Juliana Vieira Alberice, Patrícia Fatima Menegoci Eugenio, Eny Maria Vieira \\ Universidade de São Paulo, Instituto de Química de São Carlos (IQSC), São Carlos, Brasil \\ Email: *ltdcsc@gmail.com
}

How to cite this paper: Cappelini, L.T.D., Diniz, L.G.R., Fornazari, A.L., Alberice, J.V., Eugenio, P.F.M. and Vieira, E.M. (2020) Application of the Humic Substances and Ammonia in Order to Minimize Losses on Nitrogen Fertilization. Agricultural Sciences, 11, 211-222.

https://doi.org/10.4236/as.2020.113013

Received: September 23, 2019

Accepted: February 28, 2020

Published: March 3, 2020

Copyright $\odot 2020$ by author(s) and Scientific Research Publishing Inc. This work is licensed under the Creative Commons Attribution International License (CC BY 4.0).

http://creativecommons.org/licenses/by/4.0/ Open Access

\begin{abstract}
Nitrogen $(\mathrm{N})$ is an element absorbed in larger quantities by plants due to the vast number of chemical and biological reactions. Despite the high nutritional need of this element by the plants, it is not a constituent of any terrestrial rock. To avoid high production costs of $\mathrm{N}$, there is an increasing interest in the use of organic fertilizers in Brazil, including the use of humic substances (HS). In this work we evaluated the chelating properties of HS, when used together with a source of $\mathrm{N}$. The nitrogen source used in this experiment was the ammonia. We checked the optimum conditions for interaction between the HS and ammonia such as: the ratio of reaction of each compound; minimum incorporation time between these compounds and the amount of ammonia that can be adsorbed by HS (income). The best ratio of ammonia/HS was $1 / 50(\mathrm{v} / \mathrm{v})$. Higher amounts of ammonia added to $50 \mathrm{~mL}$ of HS caused a greater loss of $\mathrm{N}$. We also concluded that the application of ammonia/HS in the soil can be made immediately after their mixing, without the need of higher contact time between these substances in order to have the adsorption. No loss of ammonia was detected after 72 hours of its application together with HS. Finally, by using a factorial design, the best working area was found by settling the time of incorporation and volatilization in $24 \mathrm{~h}$, and the volumes of $\mathrm{HS}$ and $\mathrm{NH}_{3}$ in 100 and $2 \mathrm{~mL}$, respectively.
\end{abstract}

\section{Keywords}

Organic Fertilizer, Adsorption, Volatilization, Experimental Planning

\section{Introduction}

Nitrogen $(\mathrm{N})$ is an element absorbed in larger quantities by plants due to the 
multitude of chemical and biological reactions which are involved; among them, one can mention protein synthesis [1]. Despite the high nutritional need of such element by the plants, this is not a constituent of any terrestrial rock, and it is present only in the atmosphere (78\%). This fact adds to nitrogen an elevated production cost due to the high energy consumption for its industrial setting, known as Haber-Bosch process. This cost, consequently is passed on to farmers [2]. For this reason, interest in the use of organic fertilizers in Brazil has increased significantly in recent years, among them, the use of humic substances (HS).

HS are formed when substances that are considered non-humic (waxes, carbohydrates, proteins and nucleic acids), are degraded by microbial action [3]. Generally, these formed compounds are rich in carbon, hydrogen and oxygen; they can be bound to functional groups, such as $\mathrm{OCH}_{3}$ (methoxyl), $\mathrm{OH}$ (alcohols) and $\mathrm{COOH}$ (carboxyl). These humic compounds may be different because they depend on the nature of the units that constitute them [4] [5].

This organic material contains about $90 \%$ of the organic carbon reserves [6] [7], and can be divided into three parts: humin, fulvic acids, that are capable of complexing $\mathrm{Fe}, \mathrm{Cu}, \mathrm{Ca}$ and $\mathrm{Mg}$ and humic acids, formed by polymers, aliphatic and aromatic compounds, and may still form humates when combined with metals [8]. Another feature of the HS is its influence on several soil properties such as: stability of aggregates, infiltration and water retention, among others. In addition to improving the agriculture production [9], the HS decrease the costs of fertilizers and defensives, and the concern about environmental pollution is grown.

From these facts reported in the literature, this study aimed to evaluate the chelating properties of HS, when used together with a source of $\mathrm{N}_{2}$. In this work we sought to evaluate the interaction process between nitrogen and HS looking to find the optimum conditions for interaction between the HS and ammonia such as: concentration of each compound in order to avoid waste at the time of application; minimum incorporation time between these compounds and the amount of ammonia that can be desorbed by HS (income).

\section{Materials and Methods}

\subsection{Working Solutions and Reagents}

Hydrochloric acid (Sigma-Aldrich, St. Louis, MO, EUA), phenolphthalein (99\% purity) and ethanol A.R. (Merk Darmstadt, Germany). Hydrocloric acid working solutions $\left(0.1 ; 0.5\right.$ and $\left.0.1 \mathrm{~mol} \cdot \mathrm{L}^{-1}\right)$ were prepared from a $10 \mathrm{~mol} \cdot \mathrm{L}^{-1}$ stock solution, and phenolphthalein was solubilized in $95 \%$ ethanol.

Commercial grade Eurochem ammonia with 25\% nitrogen (Deutschland, Germany) was used. The HS (humic extract of the peat) was provided by Agrolatino Company located in Matão (city of state of São Paulo, Brazil).

\subsection{Procedures}

To evaluate the best ratio of interaction between ammonia and HS, the minimal 
incorporation time and the yield between these two compounds, the following standard procedure was adopted: HS and ammonia (solution A) were added in an Erlenmeyer and, in other similar container, $350 \mathrm{~mL}$ of water and three drops of phenolphthalein (solution B). This system was connected through a small glass tube with built-in tap between the flasks. At the end of each conical flask, a stopper was placed so that the ammonia would not be lost to the environment and could be quantified. This system can be seen in Figure 1.

To complete the study and better understand the system used, a series of experiments were made via factorial design to verify which factors are most influenced by the fixation of ammonia in HS.

\section{Results and Discussion}

In order to evaluate the best conditions of application of the product together with HS, the experiments were carried out using ammonia and humic substances and titrating the result of this reaction with $\mathrm{HCl} 0.1 \mathrm{~mol} \cdot \mathrm{L}^{-1}$

The first experiment assessed the amount of ammonia which may be added to $50 \mathrm{~mL}$ of HS without causing saturation of the nitrogen in the fertilizer, giving as consequence the loss of the product to the environment. The amount of ammonia was ranged from 1 to $6 \mathrm{~mL}$ (from 1 to $1 \mathrm{~mL}$ ). The values of ammonia added to HS were calculated based on the concentration applied in the different cultures $\left(200 \mathrm{~mL} \cdot \mathrm{m}^{2}\right)$ and the $50 \mathrm{~mL}$ of HS are equivalent the amount of organic material applied per hectare $\left(200 \mathrm{~m}^{3} \cdot \mathrm{ha}^{-1}\right)$. This system was left static for 24 hours, because some organic materials need to stay in rest to have a best incorporation. The resulting of the reaction was titrated after 24 hours of the tap opening among the erlenmeyers.

Observing Figure 2, it can be concluded that in this situation the best ratio of ammonia/HS is $1 / 50$ because, it can be observed that the loss of ammonia was

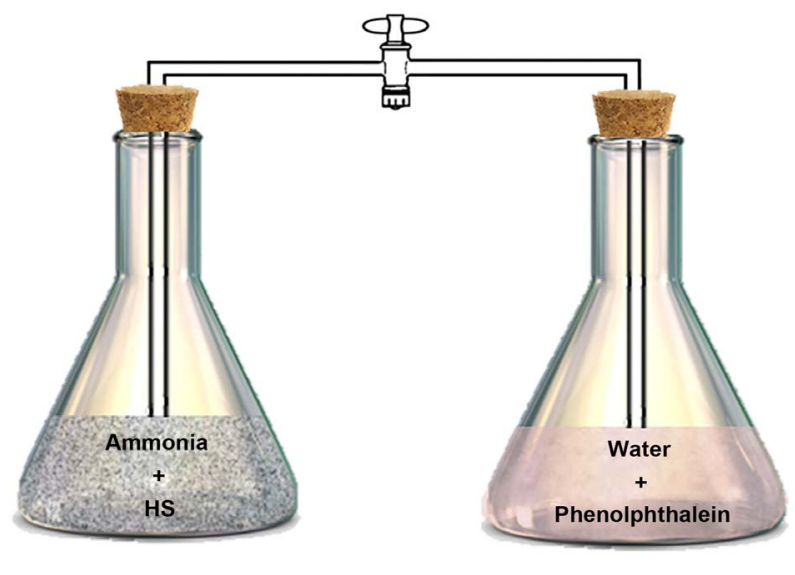

(a)

(b)

Figure 1. Scheme of the quantification of ammonia unfixed by HS (a) transferred across the tube with tap to other erlenmeyer with water and phenolphthalein (b). Both the erlenmeyers were sealed with stopper to avoid losing the environment. 


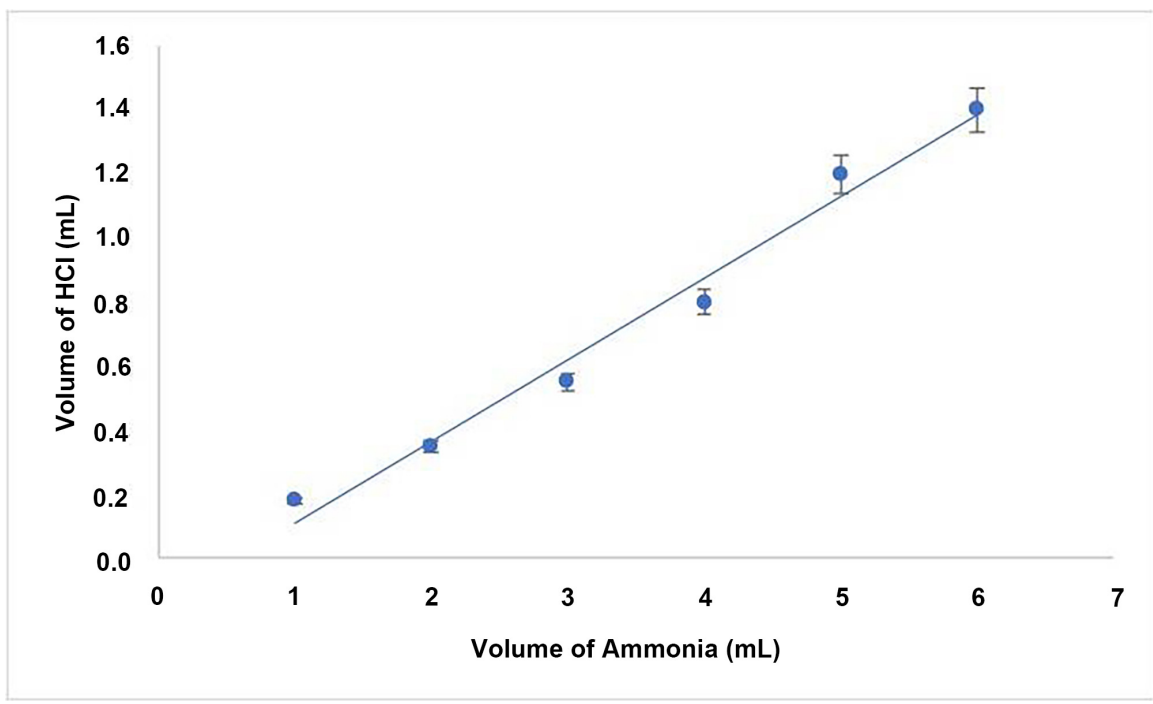

Figure 2. Titrated $\mathrm{HCl}$ volume in solution $\mathrm{B}$ (water and ammonia) when the amount of ammonia added to HS was varied for the purpose of calculating the displaced ammonia concentration of system A.

proportional when more of this source of the nitrogen was added to the organic material.

This may have been due to the absorption of ammonia and the humic substance being strongly affected by the presence of polar functional groups, such as carbonyls, carboxyls and esters, which increase $\varepsilon$ in relation to the absorption of unsubstituted rings [10]. Probably the ratio $1 / 50 \mathrm{~mL}$ was the best found due to this filling of ammonia absorption sites.

Studies have shown that urea-applied SH reduce $\mathrm{NH}_{3}$ volatilization because of their high capacity to exchange cations (CEC), acidity and high buffering capacity [11] [12]. According to [13] [14], the carboxylic and phenolic groups are the most abundant ionizable sites in HS and determine the acidic character, the CEC and the buffer capacity of the acidity. According to the literature, [11] [15] found that the application of combined urea $\mathrm{HS}$ extracted from soil reduced $\mathrm{NH}_{3}$ volatilization by $30 \%$. In addition, the mode of application and the dose of urea are also determinant in the volatilization potential [16] [17].

Losses of nitrogenized fertilizers to the environment, in recent years, proved to be a growing concern related to environmental pollution [18]. These losses, from the inadequate management and its dependence on soil and weather conditions during application, in particular the water resources, for nitrate, and the atmosphere, for nitrous oxide [18] [19], has stimulated the search for management systems that increase the efficiency of this form of fertilization with greater use of nitrogen, which is involved in a multitude of chemical and biological reactions of plant metabolism. Thus, it provides increased productivity and profitability for producers, considering the cost/benefit and sustainability of the agroecosystem [20] [21].

To confirm these results, the amount of HS in the system varied from 10 to 
$120 \mathrm{~mL}$ (10 to $10 \mathrm{~mL}$ ) using $1 \mathrm{~mL}$ of urea as established in the previous experiment. The results can be seen in Figure 3, where it was confirmed that ammonia loss is minimized when $1 \mathrm{~mL}$ of ammonia is used for $50 \mathrm{~mL}$ of the organic material. There are no reports in the literature of the average amount of urea/HS ratio that must be mixed to minimize volatilization losses, as this will depend on the nature of HS being used, as cited by Stvenson, who reports that the nature of the organic material defines the amount of ammonia that it will chelate in its structure and not the amount with which both are applied, since in the organic structures there are reactions of molecular condensation that favor the incorporation of nitrogen compounds in the structures [22] [23] [24].

Another parameter evaluated was the time required for the HS, in contact with ammonia, to be incorporated into the sites of this organic material with the purpose of reducing volatilization losses. Although there are several studies confirming the application of nitrogen along with HS, there are no studies showing its $\mathrm{N}$ time to this organic material. Thus, $50 \mathrm{~mL}$ of $\mathrm{HS}$ were placed in contact with $1 \mathrm{~mL}$ of ammonia and, in another flask, water and phenolphthalein. This system remained closed for 24, 48 and 72 hours. Then, the valves were opened and the water/phenolphthalein solution from all systems was titrated 24 hours after their opening of the system.

The volume of the titration of the three time periods were, on average, 0.83 $\mathrm{mL}$, as shown in Table 1 .

Thus, it can be observed that it is not necessary to leave the humic material and ammonia in contact for a specified time so that they are adsorbed, as the $\mathrm{HCl}$ titrated values were within $5 \%$ of experimental error. This fact shows that in the field, the application of ammonia/HS can be made immediately after mixing, without need of rest to occur adsorption between the substances.

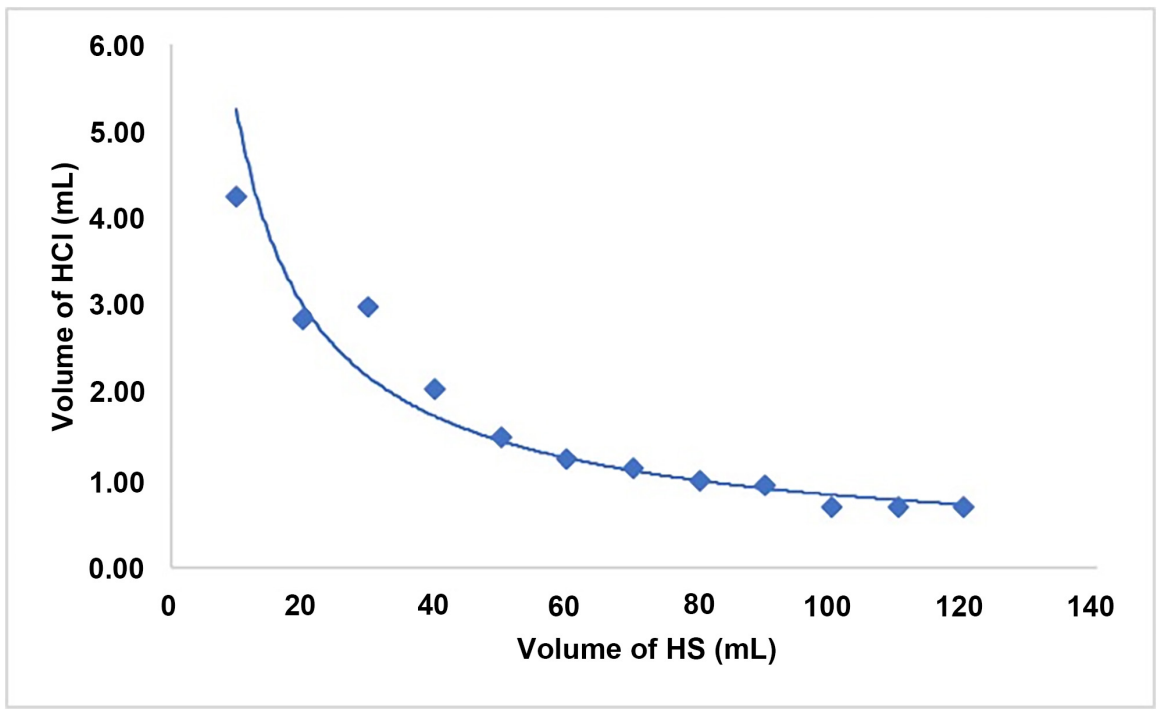

Figure 3. Titrated $\mathrm{HCl}$ volume $(\mathrm{mL})$ in solution $\mathrm{B}$ (water and ammonia) when the amount of HS added to ammonia was varied in order to calculate the ammonia concentration displaced from system A. The curve was fitted as a power function. 
Table 1. Volume of $\mathrm{HCl}$ used in the titration at different times of incorporation of HS, in contact with ammonia.

\begin{tabular}{cc}
\hline Time of incorporation $(\mathrm{h})$ & Titrated volume $(\mathrm{mL})$ \\
\hline 24 & 0.80 \\
48 & 0.85 \\
72 & 0.83 \\
Mean & 0.83 \\
\hline
\end{tabular}

In addition to assessing the time of incorporation of these two important materials for agriculture, it could also be observed the time of ammonia dissipation to the environment after its application in combination with the organic material. For this, the system described previously was kept closed for 24 hours and titrated after 24, 48, 72, 96 and 120 hours of opening the valves, thus obtaining, after each titration, the following volumes, which can be seen in Table 2 .

Observing Table 2, it is possible to conclude that there is a loss of ammonia until 72 hours after the valve is opened, after this time the system comes into equilibrium. This may also occur in the environment where an amount of nitrogen fertilizer, applied in conjunction with the HS, is lost to the environment but, after a certain time, the system stabilizes.

The $\mathrm{N}$ losses in soil may occur due to the presence of several enzymes such as $\mathrm{L}$-asparaginase, L-glutaminase, amidase and urease. Urease is the main catalyst enzyme for urea hydrolysis to $\mathrm{CO}_{2}$ and $\mathrm{NH}_{3}$ and is widely distributed in nature. The rate of hydrolysis of urea to ammonia is influenced by the type of organic material applied as well as its amount added. Furthermore, the intensity of the effect of organic matter on urease activity will depend on its availability as an energy source for microorganisms and also on the ease of microbial decomposition of organic matter [25].

According to the literature, one way to increase the efficiency of nitrogen fertilizer use may be the use of fertilizer associated with humic substances where they observed a synergistic effect on the association of humic acids from coal with urea compared to the application of conventional urea only [26]. Nevertheless, there are few studies about this mechanism by which humic acids help to increase the efficiency of nitrogen fertilizer use.

A similar study showed that the application of urea together with HS reduced its volatilization, and the period with the highest losses in these conditions was between 37 and 41 hours, similar to the one reported in this study [27] [28].

Another fact that attracted the attention of many researchers is the HS's ability to incorporate certain fertilizers, including nitrogen fertilizers, and to make controlled release of this material according to the need of plants. Thus, the capacity of incorporation of ammonia by HS was evaluated, calculating its yield from ammonia titration (without addition of HS) under the same conditions of previous experiments. The titration consumed $1.5 \times 10^{-3}$ moles of $\mathrm{HCl}$. On the other 
Table 2. Time of ammonia volatilization into the environment when applied in conjunction with the HS.

\begin{tabular}{cc}
\hline Time of volatilization (hours) & Titrated volume $(\mathrm{mL})$ \\
\hline 24 & 0.8 \\
48 & 1.4 \\
72 & 1.6 \\
96 & 1.6 \\
120 & 1.6 \\
\hline
\end{tabular}

hand, the number of moles of $\mathrm{HCl}$ consumed in the titration of a sample of aquatic ammonia together with HS under the same conditions was $1.6 \times 10^{-4}$ moles. From these results, it can be seen that $90 \%$ of ammonia is adsorbed to HS and only $10 \%$ are lost by the environment.

To better understand what are the variables that influence the most in ammonia setting by HS, it was decided to perform a $2^{4}$ full factorial design, with duplicate, generated by 10.0 Statistica software, in which four factors were studied at two different levels. The factors studied were: amounts of HS (20 and $100 \mathrm{~mL})$ and $\mathrm{NH}_{3}(2$ and $4 \mathrm{~mL})$; volatilization time (24 and $48 \mathrm{~h}$ ) and incorporation time (24 and $48 \mathrm{~h}$ ). The design generated 32 experiments that were performed randomly to avoid interference of systematic errors. Table 3 shows the factors encoded with signal " +1 " to the top level, and signal " -1 " to the lower level.

The full factorial design is used to identify which variables are more important to the studied response; observe their interactions; predict the system response in a study on a condition that has not been realized in practice; to know, in advance, how many experiments should be performed and generate less chemical and mathematical waste and save time [29]. The coding is important, since it gives equal importance to all variables, which are therefore written in a single scale, -1 and +1 , regardless of its original value. It is necessary that the experiments are carried out randomly, so that systematic errors are minimized [30].

With the factorial design, one can estimate the effect of the variables studied, and to conclude which of them were statistically significant (95\% confidence) and thus define the best fixing region of ammonia in HS, within the space of variables studied.

The generated Pareto plot confirmed that the incorporation time at the levels tested was not a significant variable, showing that the compounds can be applied immediately after mixing in the field. The most significant parameters shown in the Pareto graph were the amount of HS and ammonia that consequently encompasses the volatilization time. These conditions should be taken into account because the quantities applied will minimize the losses of this form of fertilization by volatilization (Figure 4 ).

Figure 3 shows the response surfaces obtained by $2^{4}$ factorial design with replicates, fixing the incorporation in the lower level $(24 \mathrm{~h})$, as this is not a significant 
Table 3. First $2^{4}$ factorial design, with replicates, and the encoded factors to determine the best region of ammonia fixation in HS.

\begin{tabular}{ccc}
\hline & \multicolumn{2}{c}{ Levels } \\
\cline { 2 - 3 } Factors & $(-1)$ & $(+1)$ \\
\hline $\mathrm{HS}(\mathrm{mL})$ & 20 & 100 \\
$\mathrm{NH}_{3}(\mathrm{~mL})$ & 2 & 4 \\
Incorporation (h) & 24 & 48 \\
Volatilization (h) & 24 & 48 \\
\hline
\end{tabular}

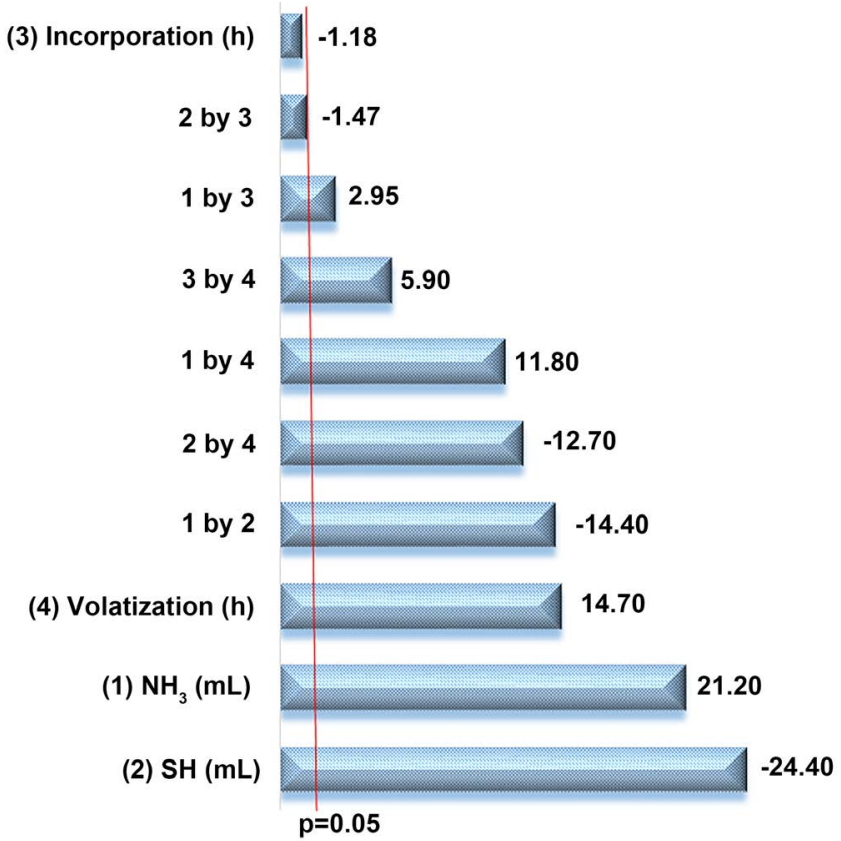

Figure 4. Pareto chart of standardized of the parameters used in fertilization.

variable and because $24 \mathrm{~h}$ is better to the process, as it is a shorter incorporation time.

In response surface of Figure 5(a) it can be seen that the greater the amount of $\mathrm{SH}(20 \mathrm{~mL})$ and the lower the amount of $\mathrm{NH}_{3}(2 \mathrm{~mL})$, there is a decrease in the volume of $\mathrm{HCl}$ titrated. In the response surface of Figure $5(\mathrm{~b})$ it is possible to observe that, when using the largest amount of SH $(40 \mathrm{~mL})$ and lower time of volatilization $(24 \mathrm{~h})$, there is a lower consumption of $\mathrm{HCl}$ for titration.

Therefore, Figure 5 shows the response surface obtained with the independent variables; volatilization and volume of $\mathrm{NH}_{3}$, leading to a better working area, utilizing a shorter time of volatilization $(24 \mathrm{~h})$ and less amount of $\mathrm{NH}_{3}(2$ $\mathrm{mL})$.

Thus, in these conditions, it can be concluded that the best working area is settling the time of incorporation and volatilization in $24 \mathrm{~h}$, and the volumes of $\mathrm{HS}$ and $\mathrm{NH}_{3}$ in 100 and $2 \mathrm{~mL}$, respectively. It is noteworthy that this planning 


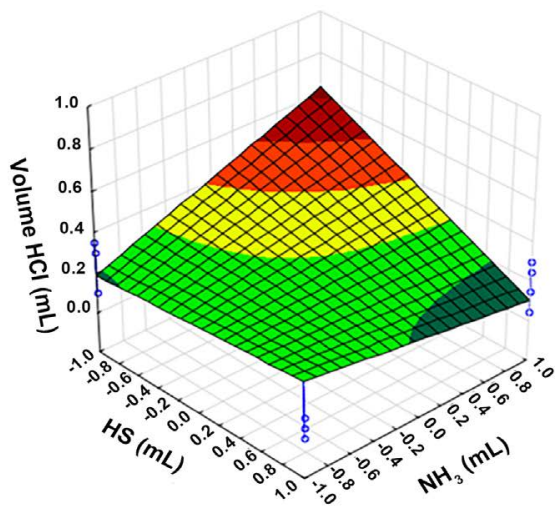

(a)

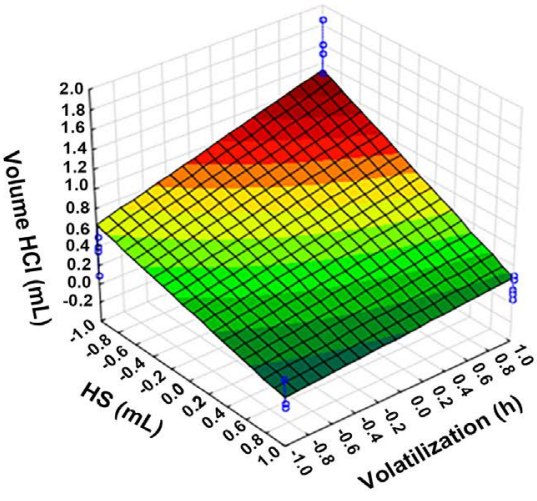

(b)

Figure 5. Response surfaces obtained by factorial planning $2^{4}$ for the purposes of the application of HS to humic acid.

was done to identify what are the significant variables for this procedure, and that additional details only point to a great area of work and cannot define the optimal working condition.

\section{Conclusions}

From these results it can be seen that it is necessary to previously evaluate the amount of SH and ammonia to be used in the field, and that the use of HS with conventional fertilizers may be an alternative, both with the aim of minimizing the environmental pollution, as to avoid the excesses, as the larger unused amount is lost to the environment, representing economic losses and unnecessary costs to the producer, also raising the value of the product within the entire production chain.

Thus, the search for management systems that increase fertilizer efficiency with increased benefit from nitrogen, increased productivity and profitability to the producer has become a major challenge in the current scenario. The currently available literature on this subject is still scarce for comparisons between methods that can be correlated to this study.

This research showed that the factorial design is a good tool, assisting in the study of the variables for fixing the ammonia in HS, leading to better working conditions with less time and lower cost of reagents.

\section{Acknowledgements}

The authors gratefully acknowledge the financial support provided by FAPESP (2014/07037-0) and CNPq (163888/2013). The authors are thankful AgrolatinoIndústria e Comércio de Adubos e Fertilizantes by the donation of the peat to carry out the work.

\section{Conflicts of Interest}

The authors declare no conflicts of interest regarding the publication of this paper. 


\section{References}

[1] Jaiswal, R., Bharambe, J., Patel, N., Dashora, A., Kothari, D.C. and Miotello, A. (2015) Copper and Nitrogen Co-Doped $\mathrm{TiO}_{2}$ Photocatalyst with Enhanced Optical Absorption and Catalytic Activity. Applied Catalysis B: Environmental, 168, 333-341. https://doi.org/10.1016/j.apcatb.2014.12.053

[2] Milton, R.D., Cai, R., Abdellaoui, S., Leech, D., De Lacey, A.L., Pita, M. and Minteer, S.D. (2017) Bioelectrochemical Haber-Bosch Process: An Ammonia-Producing $\mathrm{H}_{2} / \mathrm{N}_{2}$ Fuel Cell. Angewandte Chemie International Edition, 56, 2680-2683. https://doi.org/10.1002/anie.201612500

[3] Schaeffer, A., Nannipieri, P., Kästner, M., Schmidt, B. and Botterweck, J. (2015) From Humic Substances to Soil Organic Matter-Microbial Contributions. In Honour of Konrad Haider and James P. Martin for Their Outstanding Research Contribution to Soil Science. Journal of Soils and Sediments, 15, 1865-1881. https://doi.org/10.1007/s11368-015-1177-4

[4] Jiang, T., Skyllberg, U., Wei, S., Wang, D., Lu, S., Jiang, Z. and Flanagan, D.C. (2015) Modeling of the Structure-Specific Kinetics of Abiotic, Dark Reduction of $\mathrm{Hg}$ (II) Complexed by $\mathrm{O} / \mathrm{N}$ and S Functional Groups in Humic Acids While Accounting for Time-Dependent Structural Rearrangement. Geochimica et Cosmochimica Acta, 154, 151-167. https://doi.org/10.1016/j.gca.2015.01.011

[5] Gong, M, Nanda, S., Romero, M.J., Zhu, W. and Kozinski, J.A. (2017) Subcritical and Supercritical Water Gasification of Humic Acid as a Model Compound of Humic Substances in Sewage Sludge. The Journal of Supercritical Fluids, 119, 130-138. https://doi.org/10.1016/j.supflu.2016.08.018

[6] Pospisilova, L., Habova, M., Doleželová, E., Simon, T. and Madaras, M. (2017) Changes in Several Properties of Humic Acids after Application of Exogenous Organic Materials. Humic Substances Research, 13, 19-23.

[7] Gmach, M.R., Dias, B.O., Silva, C.A., Nóbrega, J.C., Lustosa-Filho, J.F. and Siqueira-Neto, M. (2018) Soil Organic Matter Dynamics and Land-Use Change on Oxisols in the Cerrado, Brazil. Geoderma Regional, 14, e00178.

https://doi.org/10.1016/j.geodrs.2018.e00178

[8] Feng, J. and Zhang, H. (2013) Hybrid Materials Based on Lanthanide Organic Complexes: A Review. Chemical Society Reviews, 42, 387-410. https://doi.org/10.1039/C2CS35069F

[9] Seema, Dahiya, R., Phogat, V.K. and Sheoran, H.S. (2019) Hydraulic Properties and Their Dependence on Physico-Chemical Properties of Soils: A Review. Current Journal of Applied Science and Technology, 38, 1-7. https://doi.org/10.9734/cjast/2019/v38i230355

[10] Peuravarouri, J. and Pihlaja, K. (2004) Preliminary Study of Lake Dissolved Organic Matter in Light of Nanoscale Supramolecular Assembly. Environmental Science \& Technology, 38, 5958-5967. https://doi.org/10.1021/es0400411

[11] Soares, J.R., Cantarella, H. and Campos Menegale, M.L. (2012) Ammonia Volatilization Losses from Surface-Applied Urea with Urease and Nitrification Inhibitors. Soil Biology and Biochemistry, 52, 82-89. https://doi.org/10.1016/j.soilbio.2012.04.019

[12] Rochette, P., Angers, D.A., Chantigny, M.H., Gasser, M.O., MacDonald, J.D., Pelster, D.E. and Bertrand, N. (2013) Ammonia Volatilization and Nitrogen Retention: How Deep to Incorporate Urea? Journal of Environmental Quality, 42, 1635-1642. https://doi.org/10.2134/jeq2013.05.0192 
[13] Masini, J.C., Abate, G., Lima, E.C., Hahn, L.C., Nakamura, M.S., Lichtig, J. and Nagatomy, H.R. (1998) Comparison of Methodologies for Determination of Carboxylic and Phenolic in Humic Acids. Analytica Chimica Acta, 364, 223-233. https://doi.org/10.1016/S0003-2670(98)00045-2

[14] Kah, M., Sigmund, G., Xiao, F. and Hofmann, T. (2017) Sorption of Ionizable and Ionic Organic Compounds to Biochar, Activated Carbon and Other Carbonaceous Materials. Water Research, 124, 673-692. https://doi.org/10.1016/j.watres.2017.07.070

[15] Yusuff, M.T.M., Ahmed, O.H. and Majid, N.M.A. (2009) Effect of Mixing Urea with Humic Acid and Acid Sulphate Soil on Ammonia Loss, Exchangeable Ammonium and Available Nitrate. American Journal of Environmental Sciences, 5, 588-591. https://doi.org/10.3844/ajessp.2009.588.591

[16] Dominghetti, A.W., Guelfi, D.R., Guimarães, R.J., Caputo, A.L.C., Spehar, C.R. and Faquin, V. (2016) Nitrogen Loss by Volatilization of Nitrogen Fertilizers Applied to Coffee Orchard. Ciência e Agrotecnologia, 40, 173-183. https://doi.org/10.1590/1413-70542016402029615

[17] Cancellier, E.L., Silva, D.R.G., Faquin, V., Gonçalves, B.D.A., Cancellier, L.L. and Spehar, C.R. (2016) Ammonia Volatilization from Enhanced-Efficiency Urea on No-Till Maize in Braziliancerrado with Improved Soil Fertility. Ciência e Agrotecnologia, 40, 133-144. https://doi.org/10.1590/1413-70542016402031115

[18] Zhou, M., Zhu, B., Brüggemann, N., Dannenmann, M., Wang, Y. and Butterbach-Bahl, K. (2016) Sustaining Crop Productivity While Reducing Environmental Nitrogen Losses in the Subtropical Wheat-Maize Cropping Systems: A Comprehensive Case Study of Nitrogen Cycling and Balance. Agriculture, Ecosystems \& Environment, 231, 1-14. https://doi.org/10.1016/j.agee.2016.06.022

[19] Greaver, T.L., Sullivan, T.J., Herrick, J.D., Barber, M.C., Baron, J.S., Cosby, B.J., Deerhake, M.E., Dennis, R.L., Dubois, J.J.B., Goodale, C.L. and Herlihy, A.T. (2012) Ecological Effects of Nitrogen and Sulfur Air Pollution in the US: What Do We Know? Frontiers in Ecology and the Environment, 10, 365-372. https://doi.org/10.1890/110049

[20] Martin, K.C., Bruhn, D., Lovelock, C.E., Feller, I.C., Evans, J.R. and Ball, M.C. (2010) Nitrogen Fertilization Enhances Water-Use Efficiency in a Saline Environment. Plant, Cell \& Environment, 33, 344-357. https://doi.org/10.1111/j.1365-3040.2009.02072.x

[21] Gagnon, B., Ziadi, N. and Grant, C. (2012) Urea Fertilizer Forms Affect Grain Corn Yield and Nitrogen Use Efficiency. Canadian Journal of Soil Science, 92, 341-351. https://doi.org/10.4141/cjss2011-074

[22] Stevenson, F.J. (1994) Humus Chemistry: Genesis, Composition, Reactions. John Wiley \& Sons, New York, $496 \mathrm{p}$.

[23] Khunjar, W.O., Sahin, A., West, A.C., Chandran, K. and Banta, S. (2012) Biomass Production from Electricity Using Ammonia as an Electron Carrier in a Reverse Microbial Fuel Cell. PLOS ONE, 79, e44846.

https://doi.org/10.1371/journal.pone.0044846

[24] Huang, N., Wang, P. and Jiang, D. (2016) Covalent Organic Frameworks: A Materials Platform for Structural and Functional Designs. Nature Reviews Materials, 1, 16068. https://doi.org/10.1038/natrevmats.2016.68

[25] Kandeler, E. and Gerber, H. (1988) Short-Term Assay of Soil Urease Activity Using Colorimetric Determination of Ammonium. Biology and Fertility of Soils, 6, 68-72. https://doi.org/10.1007/BF00257924 
[26] Dong, L., Yang, J., Yuan, H., Wang, E. and Chen, W. (2208) Chemical Characteristics and Influences of Two Fractions of Chinese Lignite Humic Acids on Urease. European Journal of Soil Biology, 44, 166-171. https://doi.org/10.1016/j.ejsobi.2007.07.002

[27] Huijsmans, J.F.M., Hol, J.M.G. and Hendriks, M.M.W.B. (2001) Effect of Application Technique, Manure Characteristics, Weather and Field Conditions on Ammonia Volatilization from Manure Applied to Grassland. NJAS-Wageningen Journal of Life Sciences, 49, 323-342. https://doi.org/10.1016/S1573-5214(01)80021-X

[28] Rosliza, S., Ahmed, O.H. and Majid, N.M.A. (2009) Controlling Ammonia Volatilization by Mixing Urea with Humic Acid, Fulvic Acid, Triple Superphsphate and Muriate of Potash. American Journal of Environmental Sciences, 5, 605-609. https://doi.org/10.3844/ajessp.2009.605.609

[29] Durakovic, B. (2017) Design of Experiments Application, Concepts, Examples: State of the Ar. Periodicals of Engineering and Natural Science, 5, 421-439. https://doi.org/10.21533/pen.v5i3.145

[30] Neto, B.B., Scarminio, I.S. and Bruns, R.E. (2010) Como Fazer Experimentos: Pesquisa e Desenvolvimento na Ciência e na Indústria. Bookman Editora, 414 p. 